\title{
DISCRIMINATION BETWEEN CELERY CULTIVARS WITH THE USE OF RAPD MARKERS
}

\author{
Arthur Domblides, Helen Domblides, and Victor Kharchenko
}

All-Russian Research Institute of Vegetable Breeding and Seed Production,

p/o Lesnoy Gorodok, Odintsovskij region, Moskovskaya oblast, 143080, RUSSIA

E-mail: domblidesarthur@yahoo.com

Contributed by İzaks Rašals

\begin{abstract}
Screening of celery cultivars with random amplified primers is a way of avoiding mistakes in distinguishing similar genotypes. Six primers showed distinct polymorphism between the studied cultivars. The number of bands varied from 7 to 13. Suitable primers generated 52 markers of which 22 were polymorphic. A similarity matrix was created using Jaccard's coefficient. The group average method was employed to construct a dendrogram. Based on RAPD marker profiles the cultivars were grouped into three clusters coinciding with the cultivated types, var. dulce (salad celery), and var. rapaceum (turnip celery), var. secalinum (cutting celery). The salad celery entries were similar to plants of turnip celery with similarity 0.73 , and the distance between genotypes of cutting celery and turnip celery was 0.68 . Although only 12 cultivars have been analysed, the specific product amplified with OPX1 was observed in the three studied cultivars of cutting celery.
\end{abstract}

Key words: Apium graveolens, Randomly Amplified Polymorphic DNA, molecular markers.

\section{INTRODUCTION}

Celery (Apium graveolens L. var. dulce $2 \mathrm{n}=2 \mathrm{x}=22$ ) is cultivated in Europe, North America, North Africa, India, China, and Japan. There are three known cultivated types, var. dulce Mill. (salad celery), var. rapaceum Mill. (turnip celery), and var. secalinum Alef. (cutting celery). All of them are also grown in Russia, but currently the variety of turnip celery is more popular. To provide more data on the handled cultivars and newly developed ones, there is a need to classify accurately all the accessions according to their breeding origin.

For this purpose, molecular markers in contrast to morphological characteristics are the chosen tools that can provide real and detailed information about the genetic background of the considered plants. This advantage of DNA markers is entirely suitable for cases of closely related genotype identification.

The usefulness of DNA polymorphism based on randomly amplified polymorphic DNA (Welsh and McClelland, 1990; Williams et al., 1990; Caetano-Anoles et al., 1991) has been proved in many species of vegetable crops such as tomato (Archak et al., 2002; Singh et al., 2007), cabbage (Cansian and Echeverrigaray, 2000), cucumber (Horejsi and Staub, 1996), eggplant (Karihaloo et al., 1995), melon (Garcia et al., 1998), pepper (Votava and Bosland, 2001; (Rodriguez et al., 1999), and carrot (Grzebelus et al., 1997). While there are some limitations of this type of DNA marker such as the dominant character, unreliability, strict dependence on the conditions of PCR reaction, they can, however, be very useful for genetic study of populations of vegetable plants, their wild relatives, breeding lines and hybrids. Furthermore, RAPD-based technique offers the potential of generating large number of copies enabling to characterise precisely the genome of plant species.

The twenty-one American entries of celery have been successfully screened with randomly amplified polymorphic DNA markers (Yang and Quiros, 1993). Although a linkage map including 100 RAPD markers and others has been constructed (Yang and Quiros, 1995), there are very few reports on the genetic variation among celery cultivars. Moreover, there is no report on Russian cultivar assessment. Therefore, the main aim of the present study is to classify celery genotypes since the knowledge of genetic diversity is essential for developing a systematic breeding strategy for new cultivar selection.

\section{MATERIALS AND METHODS}

Twelve varieties of different cultivated types of celery were provided by the All-Russian Research Institute of Vegetable Breeding and Seed Production (Table 1).

The total DNA was extracted from first true leaves according to the protocol of Dellaporta et al. (1983). In several 
CHARACTERISTICS OF STUDIED CELERY CULTIVARS

\begin{tabular}{|c|c|c|}
\hline Name & Cultivated type & Characteristics \\
\hline Udinka & $\begin{array}{l}\text { Turnip type, var. } \\
\text { rapaceum (celeriac) }\end{array}$ & $\begin{array}{l}\text { Mid-early harvesting, rela- } \\
\text { tive resistance to late blight } \\
\text { (Septoria apii Chest.) }\end{array}$ \\
\hline $\begin{array}{l}\text { Kornevoy } \\
\text { Gribovskiy }\end{array}$ & & $\begin{array}{l}\text { Mid-early harvesting, high } \\
\text { level of scent }\end{array}$ \\
\hline Prazhskiy gigant & & Mid-late harvesting \\
\hline Oval & & Mid-late harvesting \\
\hline Albin & & Mid-early harvesting \\
\hline Egor & & Mid-late harvesting \\
\hline Zakhar & $\begin{array}{l}\text { Cutting type, var. } \\
\text { secalium (smallage) }\end{array}$ & $\begin{array}{l}\text { Mid-early harvesting, high } \\
\text { level of scent }\end{array}$ \\
\hline Nezhniy & & Mid-early harvesting \\
\hline Sample 2/02 & & Breeding in progress \\
\hline Atlant & $\begin{array}{l}\text { Salad type var. } \\
\text { dulce (celery) }\end{array}$ & $\begin{array}{l}\text { Mid-harvesting. Resistance } \\
\text { to bolting and relative resis- } \\
\text { tance to late blight (Septoria } \\
\text { apii Chest.) }\end{array}$ \\
\hline $\begin{array}{l}\text { Golden } \\
\text { Self-blanching }\end{array}$ & & $\begin{array}{l}\text { Cultivar for mid-harvesting. } \\
\text { USA origin }\end{array}$ \\
\hline Sample 043/26 & & $\begin{array}{l}\text { Relative resistance to late } \\
\text { blight (Septoria apii Chest.) }\end{array}$ \\
\hline
\end{tabular}

difficult cases, additional purification with a mixture containing chloroform and phenol (1:1) was required.

The yield of DNA was assessed by comparing the band intensity in $1 \%$ agarose gel.

The following DNA amplifications were performed in $20 \mu 1$ volume of $10 \mathrm{ng}$ plant DNA, $0.5 \mathrm{mM}$ primer, $2.5 \mathrm{mM}$ $\mathrm{MgCL}_{2}, 0.2 \mathrm{mM}$ each of dATP, dGTP, dCTP and dTTP (SYNTOL, Russia), and 0.8 units of Taq DNA polymerase (SYNTOL, Russia). The thermal cycles used were $94^{\circ} \mathrm{C}$ for $3 \mathrm{~min} ; 36$ cycles at $94{ }^{\circ} \mathrm{C}(1 \mathrm{~min}), 37^{\circ} \mathrm{C}(1 \mathrm{~min})$ and $72{ }^{\circ} \mathrm{C}$ (1 min), and final extension $72{ }^{\mathrm{C}}$ for $10 \mathrm{~min}$. A control tube included all PCR components except genomic DNA.

Products of PCR reactions were separated by electrophoresis in $1.7 \%$ agarose gel in TBE at 60 volts. Molecular sizes of products were compared with a $100 \mathrm{bp}$ DNA ladder (MBI FERMENTAS, Lithuania). DNA fragments were visualised by ethidium-bromide staining and photographed under UV light.

Bands were scored as presence (1) or absence (0). A similarity matrix was formed using Jaccard's (1908) coefficient $\left(\mathrm{GD}_{\mathrm{j}}\right)$.

$\mathrm{GD}_{\mathrm{j}}=1-\left[\mathrm{N}_{11} /\left(\mathrm{N}_{11}+\mathrm{N}_{10}+\mathrm{N}_{01}\right)\right]$,

where $\mathrm{N}_{11}$ is the number of bands present in both individuals; $N_{10}$ is the number of bands present only in one individual; $\mathrm{N}_{01}$ is the number of bands present in the other individual. Only clearly distinct fragments in three independent reactions were included in the analysis.
LIST OF PRIMERS USED FOR CLASSIFICATION OF CELERY CULTIVARS

\begin{tabular}{l|c|c|c}
\hline \multicolumn{1}{c|}{ Primers } & $\begin{array}{c}\text { Sequence } \\
\text { (5' to 3') }\end{array}$ & $\begin{array}{c}\text { Number of } \\
\text { amplified } \\
\text { fragments }\end{array}$ & $\begin{array}{c}\text { Number of } \\
\text { polymorphic } \\
\text { fragments }\end{array}$ \\
\hline OPA08 & GTGACGTAGC & 8 & 5 \\
OPN11 & TCGCCGCAAA & 9 & 2 \\
OPX01 & GTGGGCACGA & 7 & 3 \\
OPJ05 & CTCCATGGGG & 13 & 7 \\
D4 & CATCCCGAAC & 8 & 3 \\
G2-70-2 & GGCCTACTCG & 7 & 2 \\
\multicolumn{1}{c}{ Total } & & 52 & 22
\end{tabular}

The group average method was employed to construct a dendrogram using Genstat 6 for Microsoft Windows.

\section{RESULTS}

Six primers that were selected from 37 were successfully able to discriminate the studied genotypes based on the total number of bands, polymorphic fragments, and their reproducibility in three independent amplifications (Table 2). The average number of bands amplifying per primer was 8.7. Simultaneously, the number of polymorphic fragments per primer ranged from 2 to 7 , with mean of 3.7. The fragment size varied between 250 and 1500 base pairs. The total frequency of polymorphism was $42 \%$ among celery cultivars.

Using this set of primers, the cultivars were grouped into three clusters according to the three cultivated types, var. dulce (salad celery), var. rapaceum (turnip celery), var. secalinum (cutting celery) (Fig. 1). The salad celery entries were similar $\left(\mathrm{GD}_{\mathrm{j}}=0.75\right)$ to plants of turnip celery, where as the distance between genotypes of cutting celery, and turnip celery cultivars was 0.68 . The similarity $\mathrm{GD}_{j}$ between the most distant groups, salad celery and cutting celery, was 0.67 . Turnip celery formed a relatively close sub-cluster of

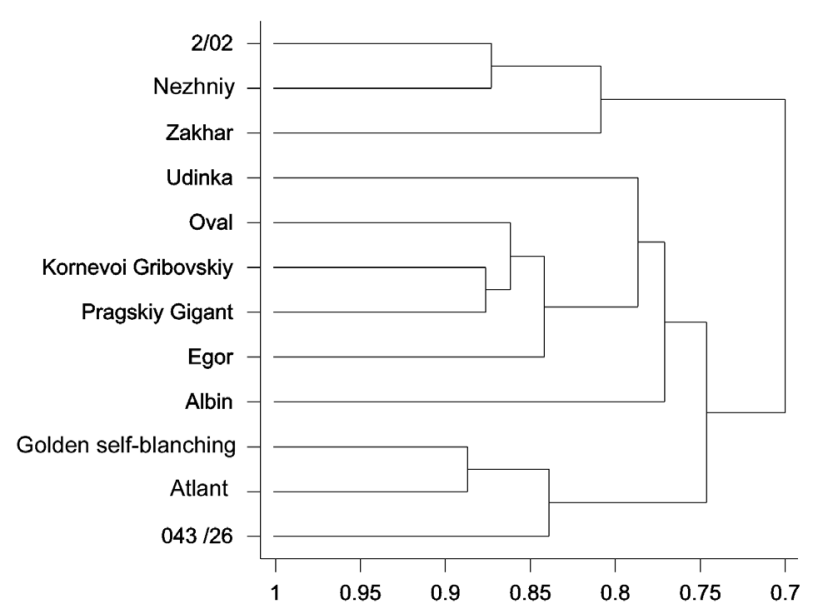

Fig. 1. Dendrogram of 12 celery cultivars by the group average cluster analysis. Similarity based on Jaccard's coefficient. 

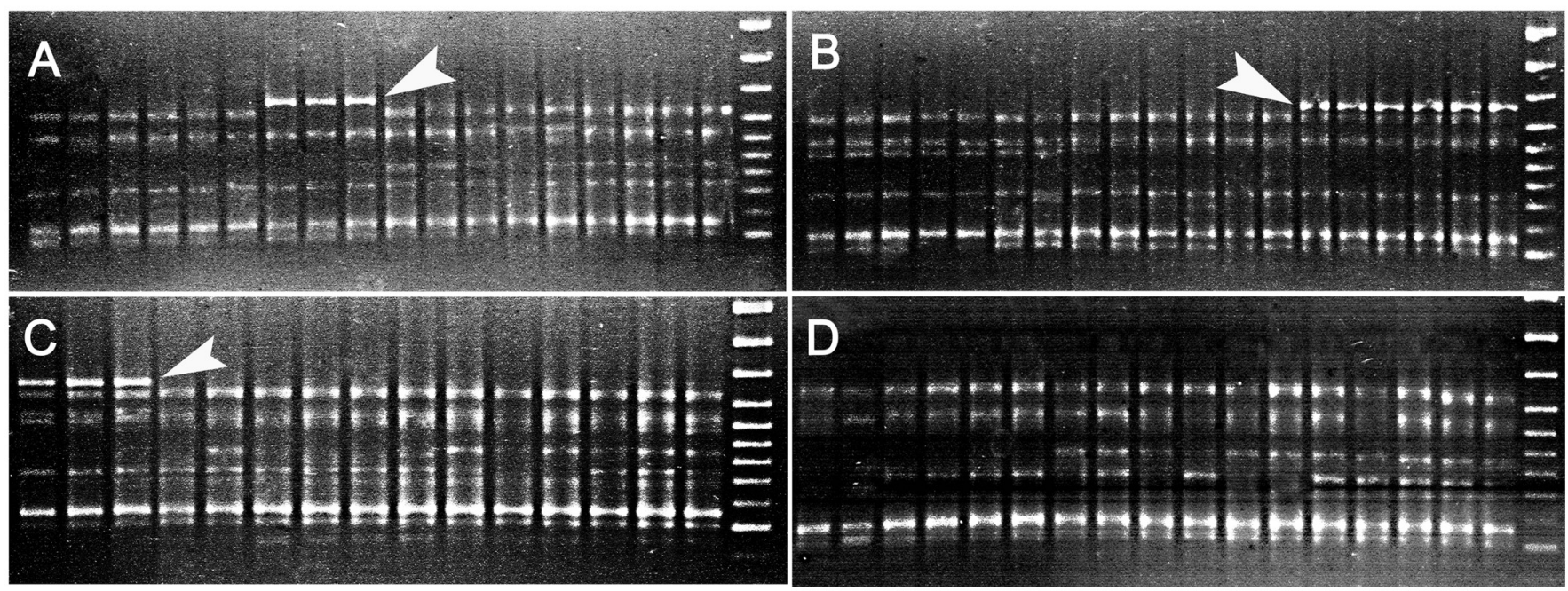

Fig. 2. Amplification products for 12 celery cultivars with primer OPX1. A, B, C, arrows indicate specific bands for the plants of cutting celery cultivars 'Zakhar', 'Nezhniy', '2/02' sample respectively; D plants of turnip and salad cultivated types.

'Oval', 'Kornevoy Gribovskiy', 'Prazhskiy Giant', and 'Egor'. A newly developed variety 'Atlant' with a distinct agronomic characteristic was also fingerprinted using selected set of RAPD primers, but no specific bands were found.

Comparisons between agronomic characteristics, cultivar origin and RAPDs clustering show some similarity. The variety 'Udinka' formed its own sub-cluster at a 78.5 level of similarity with other turnip varieties, which confirmed its long traditional use and distinct agronomic characteristics. The separately placed 'Albin' at a 77.8 level of similarity was thought to differ from the others and it has a high yield On the other hand, two varieties '2/02' and 'Zakhar', which are known to have common morphological features, were distant from each other.

The heterogeneity within the variety population was estimated for 15 plants. The RAPD profiles of 'Oval' and 'Kornevoy Gribovskiy' showed a high level of polymorphism within the variety population (polymorphism $\leq 20 \%$ ), whereas the others were genetically homogeneous (polymorphism $\leq 10 \%$ ), which was confirmed by field test.

Interestingly, although only 12 varieties were analysed, the specific product $1400 \mathrm{bp}$ amplified with OPX1 was observed in all three studied varieties of cutting celery: sample '2/02', 'Nezhniy', 'Zakhar' (Fig. 2). In fact, it could not be considered as a specified band of cutting type of celery. Most probably, it is associated with close selective breeding of the studied genotypes.

\section{DISCUSSION}

The polymorphism of RAPD markers was sufficient to discriminate the varieties with mean similarity of 0.76 , a level similar to those in with earlier reports on polymorphism in vegetable crops such as cabbage 0.82 and tomato 0.83 (Cansian and Echeverrigaray, 2000; Archak et al., 2002).
Earlier celery genetic resources were classified on the basis of agronomic characters such as shape and colour of leaves; quality of stalk for salad celery; root quality, lack of lateral roots; lack of cavities; scent level; number of leaves and yield capacity. The studied varieties represent populations that have been selected for a long time. The phenotypic classification based on these traits was somewhat confusing, particularly in the case where a new variety showed only slight dissimilarity with an extinct variety. Applying only morphological traits, it is practically impossible to discriminate the tested varieties. The biochemical characteristics are also known to be very variable, and it is based to rely solely on these results. Using RAPD polymorphism, closely related genotypes for example ' $2 / 02$ ', 'Nezhniy' and 'Zakhar', were clearly identified.

The relatively narrow genetic range, especially within the cultivated types, was observed, which can be related to the use of the same breeding material for new cultivar production for a long time. RAPD variation shows that new breeding material is required to overcome the narrow genetic range. Obviously, a search for new genes would best be achieved using new and more diverse genotypes as presently used germplasm is obviously unlikely to contain novel genes.

Although non-reproducibility is considered to be one of the major drawbacks in using RAPD markers, in this study case specific utilisation of RAPD markers in practical plant breeding has been demonstrated for celery cultivar testing.

The current study has shown that the application of RAPD markers can alleviate some of mismatches between varieties identified with morphological characteristics.

\section{REFERENCES}

Archak, S., Karihaloo, J.L., Jain, A. (2002). RAPD markers reveal narrowing genetic base of Indian tomato cultivars. Current Sci., 82, 1139-1143. 
Caetano-Anoles, G., Bassam, Gresshoff, P.M. (1991). DNA amplification fingerprinting using very short oligonucleotide primers. Bio/Technology, 9, 553-557.

Cansian, R.L., Echeverrigaray, S. (2000). Discrimination among cultivars of cabbage using randomly amplified polymorphic DNA markers. HortScience, 35, 1155-1158.

Dellaporta, S.L., Wood, J., Hicks, J.B. (1983). A plant DNA minipreparation: Version II. Plant Mol. Biol. Rep., 1(4), 19-21.

Garcia, E., Jamilena, M., Alvarez, J.I., Arnedo, T., Oliver, J.L., Lozano, R. (1998). Genetic relationships among melon breeding lines revealed by RAPD markers and agronomic traits. Theor. Appl. Genet., 96, 878-885.

Grzebelus, D., Szklarczyk, M., Michalic, B. (1997). The use of RAPD markers for genotype identification of carrot lines and F1 hybrid. J. Appl. Genet., 38A, 33-41.

Horejsi, T, Staub, J. E. (1996). Genetic variation in cucumber (Cucumis sativus L.) as assessed by random amplified polymorphic DNA. Genet. Res. Crop Evol., 46, 337-350.

Jaccard, P. (1908). Nouvelles reserches sur la distribution florale. Bull. Soc. Vaudoise Sci. Natl., 44, 223-270 (in French).

Karihaloo, J.L., Brauner, S., Gottlied, L.D. (1995). Random amplified polymorphic DNA variation in the eggplant, Solanum melongena $L$. (Solanaceae). Theor. Appl. Genet., 90, 767-770.

Received 31 October 2007
Rodriguez, J.M., Berke, T., Engle, L., Nienhuis, J. (1999). Variation among and within Capsicum species revealed by RAPD markers. Theor. Appl. Genet., 99, 147-156.

Singh, N., Singh, M., Kumar, S., Kumar, R., Singh, V., Prasanna, H.C., Rai, M. (2007) RAPD markers for hybrid seed purity testing in tomato (Solanum lycopersicum L.) Current Sci., 93(4), 462-463.

Votava, E.J., Bosland, P.W. (2001). Genetic diversity of Capsicum pubescens revealed via RAPD analysis. Capsicum and Eggplant Newsletter, 20, 60-63.

Welsh, J., McClelland, M. (1990). Fingerprinting genomes using PCR with arbitrary primers. Nucl. Acid Res., 18, 7213-7218.

Williams, J.G.K., Kubelik, K.J., Livak, K.J., Rafalski, J.A., Tingrey, S.V. (1990). DNA polymorphisms amplified by arbitrary primers are useful genetic markers. Nucl. Acid Res., 18, 6531-6535.

Yang, X., Quiros, C. (1993). Identification and classification of celery cultivates with RAPD markers. Theor. Appl. Genet., 86, 205-212.

Yang X., Quiros F. (1995). Construction of a genetic linkage map in celery using DNA-based markers. Genome, 38, 36-44.

\section{SELERIJU ŠK̦IRN̦U NOTEIKŠANA, IZMANTOJOT RAPD MARK়IERUS}

Tika meklēti RAPD marķieri, kas ļautu atšķirt fenotipiski līdzīgas selerijas šķirnes. Identificēti seši praimeri, kas uzrāda 22 polimorfus marķierus. Veikta analizēto šksirņu ǵenētiskā klasterizācija. 